\title{
Non-Privileged Applicants: Local Communities as Applicants of the Annulment Action before the European Court of Justice
}

\author{
JANJA HOJNIK \& RAJKO KNEZ
}

\begin{abstract}
In addition to the option of submitting requests for reviewing constitutionality and legality to the Constitutional Court of the Republic of Slovenia, it has been possible for the Slovenian local communities to contest EC Acts before the EC Courts over the last five years. But the terms and conditions for that are much stricter than those required by the national law. The paper analyses the complex system of legal rules determining the terms and conditions to be observed by local communities to contest the legal acts issued by the EU institutions. These conditions are very strict. They can be hardly fulfilled by local communities because equal conditions apply both to them and to legal / natural persons. For this reason, EU has been criticized for not providing an efficient system of legal remedies to protect the rights of natural and legal persons to whom also local communities pertain. The European Court of Justice partially accepted criticism, thereby facilitating contestation of EC Acts. However, it limited itself primarily to some specific areas of EC law. Wide criticism of the ECJ has led to some changes being made under the Lisbon Treaty, although these changes are not as liberal as expected.
\end{abstract}

KEYwORDs: - EC Treaty - locus standi • local communities • individual concern $\bullet$ direct concern $\bullet$ Slovenia $\bullet$ EU

CoRReSPONDENCE AdDRESS: Janja Hojnik, Ph.D, University of Maribor, Faculty of Law, Mladinska ulica 9, SI-2000 Maribor, Slovenia, e-mail: janja.hojnik@uni-mb.si. Rajko Knez, Ph.D, University of Maribor, Faculty of Law, Mladinska ulica 9, SI-2000 Maribor, Slovenia, e-mail: rajko.knez@uni-mb.si. 
The Slovenian state institutions, natural and legal persons, as well as local communities entered the dual system of the constitutional review of legality five years ago. The Slovenian Constitutional Court continues to review the legality of the Slovenian regulations under the RS Constitution. However, the legality of EC rules is reviewed by the ECJ in Luxembourg. The Constitutional Court Act provides that a request to initiate proceedings for the review of the constitutionality and legality may be submitted, inter alia, by representative bodies of local communities if the local community rights are threatened. (Rupnik et al, 2003: 299) Anyway, local communities are under no obligation to show a legal interest, which the natural and legal persons are required to do so. This has become quite complex ${ }^{1}$ in the Constitutional Court practice. Thus, the Slovenian Constitutional Court judges have, in some way, come closer to the European definition of having a legal interest in bringing an action for annulment of an act where legal and natural persons are subject to fairly stringent conditions of showing the capacity to be a party (locus standi or active legitimation) in the EC Act validity review proceedings. In this context, it is important for local communities to know that under EC law this difficult definition of legal interest also applies to them. The purpose of this paper is to analyse the situation of local communities as applicants that bring an action for annulment of an EC Act.

\section{On Action for Annulment of an EC Act in General}

The action brought for annulment of a certain EC act represents the central action against Community institutions. It is governed by the provisions of Article 230 of the EC Treaty. The purpose of this action is to achieve annulment of the binding legal acts of the EU Council, EC Commission, European Parliament or the European Central Bank. ${ }^{2}$ The proceedings need to be started within two months of the date legal action was announced or after the plaintiff has officially familiarised himself with the action. However, if the plaintiff has not become familiar with it, the EC Treaty requires that the action be brought within two months from the date the plaintiff was informed of the act. Legal action can be based on the ultra vires argument, on violation of basic procedural rules, noncompliance with the founding treaties or secondary legislation, and on the abuse of discretion argument. (Hartley, T.C., 2003: 414-432)

The EC Treaty provides that without any special conditions, actions can be brought by the Member States, EU Council, EC Commission and by the European Parliament (the Member States and the three EU institutions are called privileged plaintiffs $)^{3}$. When it comes to protecting their prerogatives, the European Central Bank and the Court of Auditors may also bring an action. When actions are brought by natural or legal persons, this option is considerably more restricted and is generally permissible only in cases where a special legal interest is shown. Its 
content is analysed below (this is why the natural and legal persons are called nonprivileged applicants of legal actions $)^{4}$.

It is provided that actions brought by natural or legal persons at first instance are heard by the Court of First Instance ${ }^{5}$, and appeals against these first-instance judgements should be brought before the ECJ which also has jurisdiction under Article 230 of the EC Treaty to regularly deal with the legal actions brought by the Member States and EU institutions. These are direct legal actions which need to be filed through an attorney with the ECJ or CFI register. The application shall be entered in the register of cases, and the Registrar shall have the notice of action published in the EU Official Journal. Then, a reporting judge and an Advocate General shall be appointed to monitor the case closely. The case shall be sent to the other party to prepare a response to the legal action in one month's time. The plaintiff has one more month to prepare a response. After that, preliminary examination needs to be carried out and the court hearing report must be provided. They will be followed by the public hearing and by the Advocate General's opinion. Finally, there are weighing the case and a verdict. The reporting judge shall prepare a draft judgment to which other judges may propose changes. After they have agreed on the final text, the judgment will be pronounced. If the plaintiff is successful in his / her action, the ECJ or the Court of First Instance will annul the pertinent act either retroactively (ex tunc) or, in some cases, merely from the announcement of the judgement on (ex nunc).

\section{The Status of Local Communities in Filing an Application}

In the enforcement of EC law, local communities have a dual nature. In the context of the principle of the direct effect of EC law, according to which natural and legal persons may invoke EC law before the national courts, local and regional communities are considered a part of the country, i.e., they pertain to a broader public sphere. On the Fratelli Constanzo case, the Court decided:

»Administrative authorities, including municipal authorities, are under the same obligation as a national court to apply (directives)."

As a consequence thereof, natural and legal persons invoking EC law (mainly referring to directive provisions) may bring actions before national courts against local communities. These plaintiffs may invoke EC law even in the cases where there are the norms that have vertical (but not horizontal) direct effect. However, they could not bring action against other private law persons. Thus, the full effectiveness of EC law is achieved.

But in relation to the capacity (locus standi) of local communities to file an action for the judgment of invalidity of EC acts, the European Court of Justice ruled that 
"an action by a local or regional entity cannot be treated in the same way as an action by a Member State, the term Member State within the meaning of the second paragraph of Article 230 EC referring only to government authorities of the Member States. That term cannot include the governments of regions or other local authorities within Member States (...) «?

This means that in the context of the capacity to be a party in proceedings for the annulment of EC acts, local communities do not fall under the framework of the country. If this were the case, then local communities would have the status of the privileged applicants of the annulment action and there would be no need for them to show a special legal interest. This status, however, has not been recognized by the European Court of Justice in its case law. Anyway, local communities as applicants of legal action for annulment are not mentioned in the EC Treaty.

Such an approach was first confirmed by the ECJ in its decision in the Regione Toscana case $^{8}$ on 1 October 1997. There is an explanation that it is apparent from the general scheme of the EC Treaty that the term 'Member State', for the purposes of the institutional provisions and, in particular, those relating to proceedings before the courts, refers only to the government authorities of the Member States of the European Communities without including the governments of regions or autonomous communities irrespective of the powers they may have. If the local and regional communities fell within the framework of the Member States, this, in the opinion of the ECJ, would undermine the institutional balance provided by the EC Treaty which, inter alia, ensures the conditions under which the Member States as signatories of the EC Treaty participate in the functioning of the Community institutions. Thus, in the opinion of the ECJ, the European Community cannot include more EC Member States than those that formally exist.

The fact that local and regional communities have no status of privileged applicants, who may bring an action for annulment of EC acts, does not mean that they cannot file any action. On the contrary, they may file an action under the same conditions that apply to natural and legal persons, i.e., to non-privileged applicants and, as their name implies, they have no privilege of the legal interest presumption, but in any case, they must prove their interest. This proof is more exacting than it is, as a rule, in the national systems of control of constitutionality and legality. It is also considerably more exacting than the Slovenian legal interest test, although the latter has been slightly tightened in the last few years.

Accordingly, local communities are non-privileged applicants of legal actions. They are legal persons acting under the fourth paragraph of Article 230 of the EC Treaty. If they file an action, the Court of First Instance is competent to judge their legal action, and only in the case of an appeal against the first-instance judgment, the $\mathrm{ECJ}^{9}$ is competent to decide on the appeal. 


\section{The Locus Standi of Local Communities as Regards EC Annulment} Action

\subsection{General}

The action for annulment brought by legal entities, which also include local communities, against an EC act, is regulated by Article 230 paragraph 4 of the EC Treaty. ${ }^{10}$ The purpose of this provision is to restrict the right of non-privileged applicants (natural and legal persons) to request judicial discretion in the ECJ regarding individual rules in relation to which the plaintiffs have a personal interest. The wording of this provision clerly indicates that the assessment procedure is possible only against one type of act, i.e., a decision. The EC Treaty specifies situations, referring to

- a decision addressed to that person;

- a decision addressed to another person which is of direct and individual concern to the apllicant;

- $\quad$ a decision in the form of a regulation which is however of direct and individual concern to the apllicant.

\subsection{Challenging Decisions}

The simplest example of challenging EC acts is challenging decisions, ${ }^{11}$ addressed to the legal action applicant. A variety of cases challenging the decisions may occur in the field of competition law in relation to the EC Commission decisions that define free competition violated by economic entities in the European market. But on the other hand, local communities usually file legal action when it comes to the rights and obligations within the framework of the Regional Development Fund.

The situation is much more complicated when a non-privileged applicant wants to challenge the validity of a decision addressed to some other person. ${ }^{12}$ The plaintiff must prove that this decision is of direct and individual concern to the applicant, which means more than showing merely a general legal interest in the case. Both criteria must be met, although direct concern can be relatively more easily proved than individual concern.

\subsubsection{Direct Concern}

To be of direct concern to non-privileged applicants, e.g., local communities, is assessed according to the existence of a causal connection between the disputed EC act and a change in the legal position of the plaintiff. Hence, this legal provision is of direct concern to the plaintiff if it has a direct effect on his legal position. The central disputed areas regarding the existence of direct concern are those acts whose effect on the plaintiff depends on the discretionary decision made 
by the addressee of the decision (e.g., a Member State). If an EU institution grants the discretion to a certain entity, e.g., to a Member State, the mere fact that such a decision, if made by the state, would affect the legal status of the plaintiff, does not yet give him the capacity to bring an action against the act of the EU institution that has granted this right. The existence of the autonomous will of the third party between the act and its effect on the non-privileged applicant implies that the act is not of direct concern to him. (Hartley, 2003: 377).

The above indications are most clearly shown in the Regione Siciliana case in which both the Court of First Instance and the ECJ dismissed the legal action brought by the Sicily Region. The courts judged that the Commission decision regarding the closure of financial assistance from the European Regional Development Fund (ERDF) for the Messina-Palermo motorway project ${ }^{13}$ was not of direct concern to the Sicily Region. It was evident from the actual conditions of the case how the Sicily Region was 'involved' in the case. Nevertheless, its direct concern was not recognized.

By issuing a decision addressed to the Italian Republic in December 1993, the EC Commission granted the ERDF financial assistance for the Palermo-Messina motorway construction in Sicily. The tasks required for the project implementation were divided into ten sets. A special regulation determined that the Community activity should be set up upon close cooperation between the Commission, the Member State concerned, and the competent bodies determined by the Member State at the national, regional, local or other levels. The decision on a grant of financial assistance indicates that the Sicily Region was determined as a responsible body for the implementation of the given project.

Problems commenced in September 1997 when the Sicily Region requested the Commission to extend the deadline for paying several sets of tasks. In its decision addressed to the Italian Ministry of Finance in October 1997, the Commission stated that all the necessary measures should be taken immediately to complete the work by the end of 1997. On the basis of the reports from the region, in February 1999, the Commission informed the Italian Ministry of Finance that the Sicily Region's obligation had not been fulfilled regarding financing the completion of the work in relation to the said project by 31 December 1997, because up to that date and with a two-year delay, only two of 10 anticipated sets of tasks were completed. Consequently, the Commission issued the contested decision, addressed to Italy, with which, on the one hand, it discharged the ERDF's obligation to pay the non-granted amounts of assistance for the expenses that became unjustified, and on the other hand, it enabled the Commission to recover the amounts the ERDF had already paid in relation to these expenses. The contested decision thus caused a 'reduction' in the ERDF financial assistance. 
In November 2002, the Sicily Region brought an action for annulment against the contested decision. The Court of First Instance rejected the action as inadmissible, basing its ruling on the fact that the contested decision was not of direct concern to the Sicily Region, but it only referred to the relationship between the EC Commission and the Italian Republic. ${ }^{14}$

The Court of First Instance recognized that, in accordance with the original decision on the grant of the contested financial assistance in 1993, the plaintiff was a body responsible for implementing the project. However, the Court judged that the contested decision could be regarded as having a direct effect on the legal position of the Sicily Region provided that on the basis of the said decision, on the one hand, it would be left with no paid amounts of the justified liabilities corresponding to the unreceived ERDF amounts on the basis of the disputed assistance, and referring to the expenses that became unjustified, and on the other hand, if it had to reimburse the unduly paid amounts equal to the amounts already received (on the basis of the indicated assistance) and allocated for the expenses that became unjustified. However, this was not the case because the Italian Republic had discretion regarding that issue.

In doing so, the Court of First Instance specially noted that on the basis of the institutional system of the Community and the rules governing the relationships between the Community and the Member States, the duty of the latter is, if there is no opposite provision of Community law, to ensure the enforcement of the Community rules in its territory. ${ }^{15}$ Regarding the funding measures taken within the framework of the ERDF, the Member States must take the necessary steps to recover any assets lost as a result of abuse or neglect. In accordance with the case law of the ECJ, it is the duty of the Member States in this system to enforce the Community rules and to take individual measures with regard to the economic entities in question. Consequently, the Court of First Instance ascertained that in this case, the Italian Republic was not prevented from paying the part exempted from the Community funding from its own resources to finance the completion of the work relating to the project in question. The correct enforcement of the contested decision only required from the Italian Republic to reimburse the unduly paid amounts listed in this decision. Consequently, the Court of First Instance concluded that the contested decision did not directly affect the legal position of the plaintiff.

Also, the ECJ ruled that setting a regional or local unit, such as Regione Siciliana, to be a body responsible for the implementation of the ERDF project, did not imply that the unit itself was entitled to assistance. Consequently, it ascertained that it was not possible to conclude that under the fourth paragraph of Article 230 of the EC Treaty, the decision directly affected this unit as a body responsible for implementing the project.(Regione Siciliana v Commission, C-417/04 P, ECR 
2006, p. I-3881. The ECJ made such a conclusion also in the recent case of Regione Siciliana v Commission, C-15/06 P, ECR 2007, p.. I-2591).

Direct concern implies that the act's implementation must be automatic and must result from the Community rules without the application of other intermediate rules (Craig \& de Burca, 2003: 518), or the discretion must already be executed, and only then can it be confirmed by the EU institution. ${ }^{16}$

\subsubsection{Individual Concern}

Unlike direct concern where there were not many contested cases, a comprehensive theory and case law have evolved in relation to individual concern.

What is of individual concern to the plaintiff is judged on the basis of the fact whether or not the plaintiff is affected by the rule in a similar way as the addressee himself. The extensive case law defining individual concern has its origin in the case of Plaumann v. Commission ${ }^{17}$ where the judgement gave the restrictive nature to the entire system of judicial review by the ECJ of legality. (Shaw, 2000: 509)

Plaumann, the sole German importer of clementines, brought an action against the Commission decision addressed to Germany where the Commission rejected the German request for the reduction of import tax on clementines in the European Community. The ECJ ruled that the non-privileged applicant, who wanted to challenge a decision which was not addressed to him, should show that the decision in question was of individual concern to him where the decision is of individual concern to non-privileged applicants provided that it

"affects them by reason of certain attributes which are peculiar to them or by reason of circumstances in which they are differentiated from all other persons, and by virtue of these factors distinguishes them individually just as in the case of the person addressed." ${ }^{18}$

According to the ECJ, the fact that the decision concerned Plaumann as an importer of clementines, i.e., due to his economic activity which could be carried out by someone else at any time, did not define the importer in the same way as the addressee of the decision.

The test for individual concern was developed by the Court of Justice in the Plaumann case. It has been used in many subsequent cases. This test is conceptually and pragmatically very restrictive and it is therefore very difficult to meet. The ECJ requires that the plaintiff belong to a closed category of entities whose membership is determined and can be defined on the day the challenged measure is taken. 
In the Toepfer v. Commission ${ }^{19}$ case, the applicant's (i.e., cereals importer's) individual concern was recognised because the contested decision concerned only those importers who, on a given day, were using the import licences with which the contested decision interfered ${ }^{20}$ :

"the only persons concerned by the said measures were importers who had applied for an import licence during the course of the day of 1 October 1963. The number and identity of these importers had already become fixed and ascertainable before 4 October, when the contested decision was made. The Commission was in a position to know that its decision affected the interests and the position of the said importers alone. ${ }^{\prime 21}$

By contrast, individual concern was not recognised in the case of Spijker Kwasten v. Commission ${ }^{22}$ in which the plaintiff, the sole Dutch importer of certain products from China, challenged the Commission decision which temporarily banned imports of all Chinese products. The plaintiff claimed that the decision was of individual concern to him. However, the ECJ had a different opinion thereby explaining that »the contested decision concerns the applicant merely by virtue of its objective capacity as an importer of the goods in question in the same manner as any other trader who is, or might be in the future, in the same situation." (para. 9)

The ECJ has also concluded that it is a measure of general nature that has an effect on the category of persons who are defined in an abstract (open) manner.

In some cases, the ECJ has also rendered an interim decision indicating that the category of the addressees of the decision is partially open and partially closed, and that the disputed act is of individual concern only to some addressees. The Piraiki-Patraiki v. Commission case $^{23}$ concerned the Commission Decision that allowed France to restrict imports of cotton yarn from Greece. This Decision was challenged by the Greek cotton-yarn producers, some of whom had already entered into contracts to export cotton yarn to France. However, due to the decision adopted, the contracts could not be fulfilled. The ECJ upheld the capacity to be a party to those plaintiffs who had already concluded those contracts, but not to others. The reason for this was in the provisions of the Act of Accession of Greece which bound the Commission (prior to taking such measures) to take into account the interests of those who were bound by contractual obligations. For this reason, the indicated entities differred from all other exporters. ${ }^{24}$ Although the ECJ allowed the action brought by some plaintiffs, the Piraiki-Patraiki case illustrates the difficulty of the Plaumann test.

The criteria, used by the ECJ to assess individual concern from the Plaumann case on, have often been criticized because they represent a considerable obstacle to 
access to the Court. Exceptions to this approach have been rare for nearly five decades (Mattli \& Slaughter, 1998: 183). Particular problems arise with regard to the self-executing acts of general application for which no national implementation is necessary. Such an act can be of direct concern to a nonprivileged applicant. If the latter maintains that the act is unlawful, he will have to violate the act itself and appeal the sanction imposed upon him by national courts for the violation. Thus, he could challenge the validity of the act in question before national courts. Such situations are obviously questionable in terms of the right to an efficient legal remedy.

\subsection{Challenging Regulations}

\subsubsection{Decisions in the Form of Regulations}

Under Article 249 of the EC Treaty, a regulation is a generally binding legal act directly applicable in law systems of the Member States. Due to its general nature, the EC Treaty restricts the ability of non-privileged applicants to challenge regulations.

It is apparent from Article 230, paragraph 4, of the EC Treaty that non-privileged applicants may only challenge regulations which are in essence decisions. In doing so, the plaintiff must prove that a formally general act is actually a set of measures, i.e., decisions that are of individual and direct concern to him. In practice, such a proof is almost impossible to implement and the ECJ has not always represented the same views on these issues.

It is relatively easy to prove that a regulation is a set of individual decisions if addressees of regulations represent an identifiable closed category, defined on the basis of some past events. The International Fruit Company case ${ }^{26}$ serves as an illustration. In this case, a group of apple importers applied to the competent national authorities for issuance of import licences. The authorities informed the Commission about that, and the latter issued a regulation with rules concerning filing applications. The regulation referred only to those applications that had been filed a week prior to that. For this reason, the ECJ ruled that the regulation was in essence only a set of individual decisions.

Anyway, when deciding, the ECJ checked whether an action requested annulment of the regulation of a general and abstract application, or annulment of the regulation whose content was individual and concrete. If it was an abstract regulation, the ECJ allowed no legal action. ${ }^{28}$ 


\subsubsection{True Regulations}

In the Codorniu case ${ }^{30}$, the ECJ allowed an action against the regulation which would not have been allowed according to the traditional approach.

Codorniu brought an action for annulment of Regulation 2045/89 which, inter alia, restricted the use of the word "crémant" for labelling certain sparkling wines, produced in the regions of France and Luxembourg. The plaintiff was a Spanish wine producer who had registered the trademark "Gran crémant de Codorniu" in 1924, and who had already used this trademark before the registration itself. The regulation adoption meant that he could no longer use the trademark which was very important ${ }^{31}$ in his business. Therefore, he challenged the said regulation by bringing an action. In defence, the Council invoked the traditional case law and the fact that Regulation 2045/89 was by its content a real regulation and not a decision. In doing so, the Council explicitly mentioned the judgement in the Deutz und Geldermann v. Council case ${ }^{32}$ which also concerned sparkling wine where the ECJ denied the admissibility of the action. In contrast to this decision, the ECJ admitted the action brought by Codorniu, thereby explaining the following:

»By reserving the right to use the term "crémant" to French and Luxembourg producers, the contested provision prevents Codorniu from using its graphic trade mark. It follows that Codorniu has established the existence of a situation which from the point of view of the contested provision differentiates it from all other traders. «(paras. 21 and 22)

The actual state of the Codorniu case indicated that the EC act interfered with the already obtained property rights of the entity, which the ECJ took into account in judgment (Šinkovec, 1994: 1-15). It also indicated that it was possible to challenge not only administrative but also legislative acts if plaintiffs could prove that an act was of direct and individual concern to them. Thus, unlike the previous case law, the ECJ ruled that a true regulation might also be of individual concern to the natural or legal enity if it had special and serious economic consequences for them (Waelbroeck \& Fosselard, 1995: 268), and that there was no need to prove that the contested regulation was in its essence a decision. However, the Court makes it clear that these economic consequences must be of such a nature that they differentiate the plaintiff from all other entities to whom the document refers. Thus, the contested act must put the plaintiff in a worse position in the market, i.e., it must affect his competitive position, the act must affect a significant share of the plaintiff's economic activities, and it must represent a serious risk to the profitability of the plaintiff's further business operations. (Gibson \& Caldeira, 1998: 71)

In light of this judgment, theoreticians have assumed that in the future, the ECJ will recognise individual concern to those plaintiffs on whom a certain EC act will 
place a particularly heavy burden in comparison with the normal burden which will be borne by the rest of the addressees of the act. (Waelbroeck \& Fosselard, 1995: 268)

Nevertheless, the legal status of non-privileged applicants did not change significantly because the ECJ continued to use the Plaumann test for all those cases where there was no breach of rights in the context of the Codorniu case. ${ }^{34}$

The Greenpeace case $^{35}$ represents the true use of the Plaumann test. In this case, the Court did not recognise individual concern to the Canary Islands residents, to Greenpeace International and to some local environmental organisations which proved concerning the Commission decision addressed to Spain, with which the Commission granted financial assistance within the framework of the regional development programme for the construction of two power stations in the Canary Islands. The plaintiffs explicitly called on the Court of First Instance to take a liberal approach to the issue of the capacity to be a party so that the latter could be justified not only for pure economic reasons but also in terms of environmental protection. They maintained that in all Member States there were environmental protection associations (being sufficiently representative or meting certain conditions) entitled to challenge administrative decisions that supposedly infringed the environmental protection legislation. The Court of First Instance did not accept the request for the assessment of environmental interests which were supposed to be affected. The Court used the Plaumann test completely. It concluded that the challenged decision concerned individual plaintiffs in the same manner as all other people living in or visiting that area. Therefore, it could not be of individual concern to them. The ECJ passed the same judgment on the organisations which had filed an action, because the Court found no specific circumstances that would differentiate organisations from their members. In the appellate procedure before the $\mathrm{ECJ}^{36}$, the Advocate General Cosmas suggested preserving the views established in the case law so that no exceptional position would be recognised for environmental organisations. Otherwise, "natural persons having no capacity to be a party under the fourth paragraph of Article 173 (now 230) of the EC Treaty could circumvent this procedural obstacle by establishing environmental organisations (...). Their number could theoretically rise to infinity" "37. Consequently, the ECJ ruled that the interpretation of the fourth paragraph of Article 230 of the EC Treaty, given by the Court of First Instance, was in line with the established case law of the ECJ. 


\subsubsection{The Netherlands Antilles Case}

The Netherlands Antilles case ${ }^{38}$ falls under the cases where invalidity of an act was enforced by a regional community to which no individual concern was recognised.

Regarding imports of rice from the overseas countries and territories, the Council of the European Union issued Regulation 304/97 in 1997. On its basis, the Commission adopted Regulation 764/97 in which it set the import quota on rice from these countries. It also exempted them from customs duty on a total of 70,000 tonnes of rice for the period from 1 May to 30 September 1997. On 2 June 1997, the EU Council adopted Regulation 1036/97 that cancelled Regulation 764/97. The difference lay in the quotas, which were considerably reduced for the Netherlands Antilles, and in the period of use.

The Netherlands Antilles maintain that the Constitution of the Netherlands guarantees the status of one of the three territories of the Netherlands, and that they alone can represent their interests because the latter have not always been defended by the Netherlands. Under Dutch law, the Netherlands Antilles have an autonomous status. Therefore, when challenging Regulation 1036/97, they believed there was no need for them to show direct and individual concern because they had a similar status to that of the European Parliament at the time of the case, i.e., they were competent to bring an action for annulment in order to protect their prerogatives. The ECJ did not accept this argument and ruled that the Antilles could challenge the EC act only under Article 230, paragraph 4, of the EC Treaty, i.e., as natural and legal persons thereby showing direct and individual concern because the disputed regulation was not addressed to them.

While direct concern was not at issue, the ECJ believed that the Netherlands Antilles were not individually affected by the disputed regulation because it referred to the imports of rice from all the overseas territories. The Court also believed that the overseas territories had only a general interest in increasing economic prosperity which was not sufficient to mark them as individually affected by the disputed regulation.

Moreover, the ECJ also stressed that the EU Council might be committed to taking into account the negative consequences of the regulation for some of the territories (other territories improved their situation thanks to the new regulation), but this evidence did not exonerate the Netherlands Antilles from being different from all other entities. Their difference was not satisfactorily represented even by the fact that the Netherlands Antilles exported far more rice to the EU than all the overseas territories did. The ECJ judged that evidence of important socioeconomic consequences for the Netherlands Antilles due to the new regulation had not changed the fact that the regulation had similar consequences also for other 
overseas territories. The ECJ concluded that rice processing was an economic activity that could be carried out in any country. Therefore, the Netherlands Antilles did not differ from other territories.

In addition to challenging the validity of Community acts, the legal interest test is also used when local communities and other non-privileged applicants request issuance of interim relief. In accordance with the established case law, the issue of the inadmissibility of the action must not be tested within the framework of the proceedings for interim relief in order to prevent prejudicing the substance of the case. However, the plaintiff must show the probable admissibility of the action with which the proposal to issue interim relief is associated. The ECJ explains that through the proceedings for interim relief, this is the only way to prevent deferment of carrying out the action regarding which the Court of First Instance can subsequently dismiss annulment later on, because it considers that the legal action (after evaluating the cause of action) is inadmissible (see Order of the ECJ President in the case of Pfizer Animal Health v Council, P(R), ECR 1999, p. I8343, item 89).

However, such an examination of the admissibility of the main action is necessarily summary because the proceedings for interim relief are by nature urgent (see Order of the ECJ President in the case of Federación de Cofradías de Pescadores de Guipúzcoa and Others v Council, C-300/00 P(R), ECR, p. I-8797, item 35 .

In the context of the proposal to issue interim relief, the admissibility of the main action is only roughly examined so that the action is marked as inadmissible, provided that its admissibility can be completely excluded.

In the Autonomous Region of Azores, (see Case T-37/04 R Região autónoma dos Açores v the Council of the European Union, ECR 2004, p. II-2153) the President of the European Court of First Instance checked whether at first glance, it met the conditions for the capacity to be a party (locus standi) under the fourth paragraph of Article 230 of the EC Treaty. Região Autónoma dos Açores (Autonomous Region of Azores) is an autonomous region of the Portuguese Republic and, under Portuguese law, it has legal personality and, under the Portuguese Constitution, significant autonomous powers, including the adoption of the Fishing Act. The region challenged the EC regulation regarding fisheries as unlawful (see Council Regulation (EC) No 1954/2003 of 4 November 2003 on the management of the fishing effort relating to certain Community fishing areas and resources, OJ 2003 L 289, p. 1.).

It has asserted that the challenged regulation directly interferes with its legislative power and competence to regulate the issue of fishing in the waters that fall under its jurisdiction because the effects of the challenged regulation are directly derived 
from it because the Member States, particularly Portugal, are unable to adopt any implementation measures. Regarding an individual interest, the Azores region has asserted that the regulation explicitly recognizes its special position. However, the regulation takes away its competence to regulate fishing in the waters of the Azores due to which the regulation is of individual concern to the region.

The order of the President of the European Court of First Instance stresses that, in principle, the region may bring an action for annulment of an EC act within the scope of national law according to which it enjoys legal personality whereat the region has the position of a non-privileged applicant (item 112). However, the President has stressed that in an action for annulment, the general interest, which the region as a competent entity involved in dealing with economic issues may have in its territory, is not sufficient in itself for the outcome of the legal proceedings that would be beneficial to its economic growth. Therefore, the region cannot be considered to be individually concerned under the fourth paragraph of Article 230 of the EC Treaty. Moreover, the fact that the pertinent region is explicitly and precisely stated in the regulation is not enough to show individual interest (items 116-119). In this part, the order of the President of the European Court of First Instance shows the strictness of the Plaumann test and the difficult situation of local communities as plaintiffs before the ECJ because it is extremely difficult for them to prove individual concern in the cases where they want to improve economic or other situation of the entities in their area.

Nevertheless, in the proceedings for interim relief, the aggregate nature of the legal interest test somewhat mitigates this strictness. Thus, in the Azores Region case, the President of the European Court of First Instance has stressed that although there are serious doubts as to whether or not the plaintiff shows the condition of individual concern, i.e., that the challenged regulation affects it differently than the other exceptionally marginal regions, it is not possible to completely exclude the fact that the Azores Region is able to prove that the challenged regulation is of individual concern to it. On this basis, the President has ascertained that since the admissibility of the main action cannot be completely excluded at the stage of deciding on interim relief, the proposal for interim measures cannot be rejected merely on grounds of inadmissibility (items 124125). On 1 July 2008, the Court of First Instance dismissed the Azores Region's main action as inadmissible.

\subsection{Challenging Directives}

Directives can be challenged by non-privileged applicants. Directives as acts of contestation are not specified in the fourth paragraph of Article 230 of the EC Treaty. The reason for this lies in their nature. They only bind the Member States as to the objectives to be achieved, and the directive implementation mode can be freely selected under domestic legislation. The directive establishes a legal 
relationship between the EC and the addressee State so that, in general, directives do not grant direct rights to natural and legal persons, except in the case where the directive is not implemented (by the state) into domestic legislation in a timely or correct manner. The legal rule which natural or legal persons invoke has a direct effect.

Nevertheless, the ECJ has taken the position that there is no reason to belive that challenging directives is not possible. In the UEAPME $v$ Council case ${ }^{39}$, the ECJ gave the following explanation:

"Although Article (230), fourth paragraph, of the Treaty makes no express provision regarding the admissibility of actions brought by legal persons for annulment of a directive, it is clear from the case-law of the Court of Justice that the mere fact that the contested measure is a directive is not sufficient to render such an action inadmissible (...). In that respect, it must be observed that the Community institutions cannot, merely through their choice of legal instrument, deprive individuals of the judicial protection offered by that provision of the Treaty (...) the mere fact that the chosen form of instrument was that of a directive cannot in this case enable the Council to prevent individuals from availing themselves of the remedies accorded to them under the Treaty."

The non-privileged applicant may assert that in its essence, a formal directive is actually a decision that is of individual and direct concern to him. With respect to the difficulty of proving the admissibility of challenging regulations, the real possibilities for successful challenging the directives are certainly very slight. However, it is important that the issuer of the act cannot circumvent the challenge rules merely by adopting the pertinent act in a form of the directive which will not be this by content at the same time.

\section{$5 \quad$ Alternative Ways}

The restricted admissibility of actions brought under Article 230 of the EC Treaty is attempted to be substituted in different ways through other legal channels. Preliminary ruling proceedings and action for damages against Community are most frequently mentioned as alternatives to the legal action under Article 230 of the EC Treaty.

\subsection{Preliminary Ruling Proceedings under Article 234 of the EC Treaty}

National courts are involved in the procedure for the review of the validity of Community acts under Article 234 of the EC Treaty which empowers them and sometimes binds them to address the issue to a preliminary ruling on the legality of a Community act used in a specific decision-making process. 
The advantage of the procedure set out in Article 234 of the EC Treaty is that the conditions for the capacity to be a party are less stringent than for the invalidity action. Many cases prove that individuals and legal entities have challenged the validity of EC regulations and decisions. They would not be able to do so directly before the ECJ or the Court of First Instance. ${ }^{48}$ The challenged regulations were general market regulations. If they were brought before the court by nonprivileged applicants, they would most likely be declared inadmissible. These regulations violated general legal principles or the provisions of the EC Treaty, or it was about exceeding competences. Since the Community is based on law observance, the review of legality was allowed before the ECJ. (Arnull, 1995: 40)

However, the question arises whether natural and legal persons, including local communities, really can choose between procedures under Article 230 and under Article 234 of the EC Treaty. This issue was explained in the TWD Textilwerke case $^{49}$ in 1994. The plaintiffs did not bring an action under Article 230 of the EC Treaty. Therefore, a question arose whether they had the right to bring an action under Article 234 before the national court. The ECJ ruled that legal certainty reasons prevented the plaintiff from challenging the disputed EC act under Article 230 of the EC Treaty. However, he allowed the deadline for that to expire (challenge under Article 234 of the EC Treaty). So, natural and legal entities cannot initiate proceedings before national courts with a view to request a preliminary ruling on the validity of EC acts if the proceedings under Article 230 of the EC Treaty are »undoubtedly« available. ${ }^{50}$ The problem is that it is not always easy to judge whether or not natural and legal persons belong to the group of plaintiffs who must quickly bring an action under the fourth paragraph of Article 230 of the EC Treaty. ${ }^{51}$ (Lengauer, 2005:577)

\subsection{Actions for Damages against the Community under the Second Paragraph of Article 288 of the EC Treaty}

A second alternative to natural or legal persons is an action for damages against the Community. ${ }^{52}$ The conditions for receiving indemnification have been formed by the ECJ through its case law. Within this framework there are important situations in which non-contractual liability stems from a binding EC act. In order to receive indemnification, it is necessary to prove the existence of an unlawful act, the damage caused, and the existence of a causal connection between the unlawful act and the damage caused. Unlike the initial case-law, since the time of the Lütticke $v$ Commission case ${ }^{53}$ it has no longer been necessary to first obtain the findings on the invalidity of the act because the action for damages is an autonomous action. In the case of Aktien-Zuckerfabrik Schöppenstedt $v$ Council, ${ }^{54}$ the ECJ has clearly shown the difference between an action for damages and an action for annulment of an EC act, thereby proclaiming that the purpose of an action for damages is not to annul the disputed act, but to receive compensation 
for damage caused by an EC institution. Despite this, the Court must establish an unlawful act. The judgement indicates that

»the non-contractual liability of the Community presupposes at the very least the unlawful nature of the act alleged to be the cause of the damage, where legislative action involving measures of economic policy is concerned, the community does not incur noncontractual liability for damage suffered by individuals as a consequence of that action, (...) unless a sufficiently flagrant violation of a superior rule of law for the protection of the individual has occurred.« (para. 11)

The conditions for receiving indemnification under this formula are very strict. This is why only few legal actions have been successful. (Costa, 2003) These stringent conditions, of course, stir doubts about efficiency of this alternative action under Article 230 of the EC Treaty.

\subsection{Action for Annulment under the Lisbon Treaty}

Within the framework of the Convention on the Future of Europe, the draft EU Constitution was being drawn up by the special working group II that had the working title of "Incorporation of the Charter / Accession to the ECHR." It examined the issue whether the existing system of resources, available to individuals to challenge acts of institutions, needed renewal in the light of the fundamental right to efficient judicial protection, recognised by the ECJ case law, and under the provision of Article 47 of the Charter of Fundamental Rights which guarantee the right to efficient judicial protection. This group believed that there was no need to amend the provisions of the fourth paragraph of Article 230 of the EC Treaty. Due to work-group differences in attitude, the Convention Secretariat established a discussion circle in which some amendments to the provisions discussed were nevertheless presented. Although the EU Constitution has not been ratified by all Member States and thus it has not yet entered into force, the amendments to this provision have been taken into account in the Lisbon Treaty (Article 263 of the Treaty on the Functioning of the European Union) under which natural and legal entities, including local communities, will be entitled to challenge

- the acts addressed to them; these acts will continue to be decisions in particular;

- the acts which are not addressed to them, but they are of direct and individual concern to them; in comparison with current law, this definition here includes legislative acts that, under certain conditions, can be of direct and individual concern to an individual; this has already been recognised by the ECJ in the Codorniu case; however, this is not explicitly defined in the EC Treaty; 
- the rules that are of direct concern to them, but they need no implementing measures; this option will cover the existing gap in the system of legal remedies.

In view of challenging EC acts, it needs to be noted that the Commission has proposed a clear regulation of challenging the acts of agencies and other bodies of the Union because the existing Article 230 of the EC Treaty does not indicate the acts of these bodies. Their verification is regulated by the constituent instruments of individual bodies, but the practice is very patchy. Proceeding from the principle of efficient judicial protection, the Lisbon Treaty amends Article 230 of the EC Treaty so that in the fifth paragraph, it provides that specific conditions shall be laid down in the founding acts of the bodies, offices and Union agencies. There shall also be details provided for actions brought by natural or legal persons against the acts of these bodies, offices or agencies intended to produce legal effects.

In the light of local communities, there is an important novelty that the Committee of the Regions, an advisory body of the European Union, has been ranked among semi-privileged applicants bringing actions for annulment so that competent authorities can challenge EU acts in the future if they are adopted contrary to the principle of subsidiarity. This is an important acquisition of the Committee of the Regions that represents the interests of local and regional communities within the EU legislative process. However, restrictions on bringing an action for annulment for violation of the principle of subsidiarity significantly reduce the importance of this acquisition by taking into account the adverse opinion of the ECJ about the annulment of EC acts due to breach of the principle of subsidiarity. This is clearly shown by its decision in the case in which the United Kingdom challenged the Working Time Directive (United Kingdom v Council, Case C-84/94, ECR 1996, p. I-5755).

The ECJ has concluded that "the requirements of the subsidiarity principle are met by the Council's decision to accept legislation." The ECJ understands this principle as a political principle, and the Court is usually not ready to deal with conflicts regarding appropriate division of powers between EU institutions, Member States and local communities. Consequently, the Committee of the Regions is expected to be successful to a limited extent in challenging the validity of EC acts because the latter excessively interfere with the competences of local communities. 


\section{Conclusion}

Stringent conditions for challenging EC acts indicate that local communities are very restricted when bringing an action for invalidity in Luxembourg. Consequently, theory and practice largely advocate the need for changes that would establish an efficient system of legal remedies to provide the most appropriate legal way for pertinent entities in any situation. Regarding the annulment of EC acts, in most cases, the most appropriate ways are the proceedings under Article 230 of the EC Treaty directly before the Court of First Instance and the ECJ which are the sole courts competent to judge the validity of EC acts. Also, in the light of legal security, a short deadline for bringing an action urges the pertinent entities to react rapidly.

The existing wording of the fourth paragraph of Article 230 of the EC Treaty may have corresponded to the original design of the European Economic Community. However, in the next half century, the Member States delegated more and more powers to the supranational level. Therefore, today we can no longer speak of the European Union as a traditional international community in which natural and legal entities are marginalized. This development justifies and requires modifications to ensure greater judicial protection of natural and legal persons than it is in the existing system. It is true that the EC Treaty has not remained unchanged since its original form, and that the politicians could have changed the conditions for enabling natural and legal persons to have access to the ECJ. Anyway, the European judges are those who are familiar with law and with the needs of the legal system. Therefore, they are competent to seek the ways which, despite political silence, comply with the requirements for an efficient and fair system of judicial protection.

Local and regional authorities also play an increasingly important role in the EU system because they are protagonists of democratic legitimacy by bringing decision-making closer to EU citizens. As such, they have increasingly important tasks to perform within the Member States, and it is certainly not in accordance with the democratic principle that their capacity to challenge EC acts is so restricted. To a certain extent, the case law has developed in the direction of greater liberalisation of rights, particularly in certain areas, and it has emphasised the principle of efficiency as a fundamental principle of EC law, but this principle seems to be only on paper because it does not allow interpretation of some provisions of positive law in accordance with it. The wording of the Lisbon Treaty anticipates some changes in the conditions of challenging, although there will be no large-scale changes. But on the other hand, the fate of the Lisbon Treaty itself is still uncertain... 


\section{LEX LOCALIS - REVIJA ZA LOKALNO SAMOUPRAVO J. Hojnik \& R. Knez: Non-Privileged Applicants: Local Communities as Applicants of the Annulment Action before the European Court of Justice}

\section{Notes}

${ }^{1}$ It is determined that the legal interest in the initiative to be submitted by natural and legal persons is given if the rule or general act for execution of public powers, whose assessment is proposed by the initiator, directly interferes with his rights, legal interests or legal position. In its decision in 2003 (Decision of the Constitutional Court of the Republic of Slovenia, No. UI74/03 of 23.10.2003), the Constitutional Court decided to give new meaning to the word "directly" under Article 24 of the Law, and it changed the previous position on the basis of which it widely recognized the legal interest in challenging the statutory provisions already on the basis of the fact that the initiator proved the initiation of proceedings in which the two challenged statutory provisions were supposed to be used. Thus, it holds good now that in the cases, in which the initiator secures his intention, pursued by the initiative, and secures it in individual proceedings before the court, and then with a constitutional complaint, he shows no interest in submitting an initiative.

2 The first paragraph of Article 230 of the EC Treaty provides: »The Court of Justice shall review the legality of acts adopted jointly by the European Parliament and the Council, of acts of the Council, of the Commission and of the ECB, other than recommendations and opinions, and of acts of the European Parliament intended to produce legal effects vis-à-vis third parties.«

3 The European Parliament was given unlimited possibilies to challenge EC acts as late as February 2003 when the Treaty of Nice came into force.

${ }^{4}$ Local and regional communities also belong to them as explained below.

5 Jurisdiction to hear and determine direct actions brought by natural and legal persons was granted to the Court of First Instance in March 1994 by Council Decision No. 94/149 Council Decision of 7 March 1994 amending Decision 93/350/Euratom, ECSC, EEC amending Decision 88/591/ECSC, EEC, Euratom establishing a Court of First Instance of the European Communities Official Journal L 066 , 10/03/1994 p. 0029 - 0029.

${ }^{6}$ Fratelli Constanzo SpA v Comune di Milano, Case 103/88, ECR 1989, p. 1839.

${ }^{7}$ Regione Siciliana v Commission, Case C-417/04P, ECR 2006, p. 3881.

${ }^{8}$ Regione Toscana v Commission, Case C-180/97, ECR 1997, p. I-5245.

9 See also the Judgment of the Court of 22 November 2001 in the case of The Netherlands Antilles v Council, C-452/98, ECR 2001, p. I-8973, para. 50.

${ }^{10}$ It provides that $»$ Any natural or legal person may, under the same conditions, institute proceedings against a decision addressed to that person or against a decision which, although in the form of a regulation or a decision addressed to another person, is of direct and individual concern to the former."

11 Decisions are acts of an administrative nature which are fully binding on the person to whom they are addressed (Article 249 of the EC Treaty).

12 Some other person under Article 230 of the EC Treaty is most frequently a Member State (Plaumann v Commission); the addressee can be a company, and there are affected workers in the company or economic association - see P. Grilc, European Union Law, Faculty of Law and Cankarjeva založba (Publishing House), 2001, p. 293.

${ }^{13}$ Commission Decision D (2002) 810439 of 5 September 2002 closing the financial assistance from the European Regional Development Fund (ERDF) for the Messina-Palermo Motorway major project (ERDF No 93.05.03.001 - ARINCO No 93.IT.16.009).

${ }^{14}$ Regione Siciliana v Commission, Case T-341/02, ECR 2004, p. II-2877.

${ }^{15}$ See, e.g., ECJ Judgments, the case of Deutsche Milchkontor and Others v Germany, 205/82 to $215 / 82$, ECR. 1983, p. 2633, and the case of Étoile commerciale and CNTA v Commission, 89/86 and 91/86, ECR 1987, p.. 3005. 
16 Another example is the case of International Fruit Company, 41-44/70, ECR. 1971, p.. 411; for direct concern in detail, see Arnull A., Private Applicants and the Action for Annulment since Codorníu, 38 CMLRev 2001, pp. 25-30.

17 Plaumann v Commission, Case 25/62, ECR 1963, p. 95.

18 Plaumann Judgment, para. 107.

19 Toepfer v Commission, cases 106-107/63, ECR 1965, p. 405.

${ }^{20}$ Similarly, see judgment in the case of Bock v Commission, 62/70, ECR 1971, p. 897.

${ }^{21}$ Judgment in the Toepfer case, page 411, para. 8.

22 Spijker Kwasten v Commission, Case 231/82, ECR 1983, p. 2559

23 Piraiki - Patraiki v Commission, Case 11/82, ECR 1985, p. 207.

24 Similarly, in the Sofrimport case, the ECJ judged that the regulation, which allowed protectionist measures to limit imports of apples from Chile, gave specific protection to the importers whose apples were in transit at the time measures were taken - Sofrimport Sarl v. Commission, Case C - 152/88, ECR. 1990, p.. I-2477.

25 An open category is where the membership is neither fixed nor determined when the measure comes into force; a closed category is where the membership is fixed and members are individually determined; therefore, the regulation is of individual concern to them.

${ }^{26}$ International Fruit Company BV v Commission, Cases 41-44/70, ECR 1971, p. 411.

${ }^{27}$ Case 138/79, ECR 1980, p. 3333.

${ }^{28}$ Calpak SpA \& Società Emiliana Lavorazione Frutta SpA v Commission, Cases 789-790/79, ECR 1980, p. 1949.

29 "There is only a very limited number of Williams pears processors in the Community" - fifth paragraph of the judgment.

30 Codorniu SA v Council, Case C-309/89, ECR 1994, p. I-1853. This was one of the last adjudicated cases prior to transfer of direct actions brought by non-privileged applicants to the Court of First Instance.

${ }^{31}$ Codorníu produced around 11 million bottles of wine »Gran Crémant de Codorníu per year.

32 Case 26/86, ECR 1987, p. 941; in paragraph 12, the ECJ stated: »...the contested measure concerns the applicant only in its capacity as a sparkling-wine producer which has traditionally used a particular method of production in just the same way as any other producer or trader in the same position."

33 Antillean Rice Mills NV v Commission, Cases T-480\&483/93, ECR 1995, p. II-2305.

34 Kik v Council and Commission, Case T-107/94, ECR 1995, p. II-1717; here, plaintiff attempted to challenge the language regime introduced by the Community Trade Mark Regulation where it excluded the plaintiff's language, i.e., Dutch. The Court did not uphold his capacity to be a party, and despite the plaintiff's invoking the provisions of the European Convention on Human Rights, the Court used the Plaumann test in accordance with the traditional case law.

${ }^{35}$ Greenpeace and Others v Commission, Case T-585/93, ECR 1995, p. II-2205.

36 Stichting Greenpeace Council (Greenpeace International) v Commission, Case C-321/95 P, ECR 1998, p. I-1651.

37 Opinion of Advocate General Cosmas delivered on 23 September 1997, paragraph 117.

38 Netherlands Antilles v Council, Case C-452/98, ECR. 2001, p. I-8973. Under Article 3 (1)

(s) of the EC Treaty, the Community activities include the association of the overseas countries and territories with the Community to increase trade and joint economic and social development.

39 Union Européenne de l'artisanat et des petites et moyennes entreprises (UEAPME) v Council, Case T-135/96, ECR 1998, p. II-2335. 


\section{LEX LOCALIS - REVIJA ZA LOKALNO SAMOUPRAVO J. Hojnik \& R. Knez: Non-Privileged Applicants: Local Communities as Applicants of the Annulment Action before the European Court of Justice}

40 The Court of First Instance invoked the Gibraltar v Council case, C-298/89, ECR 1993, p. I-3605 where the ECJ has said that the "word 'decision', used in paragraph 2 of Article 173 (now paragraph 4 of Article 230) of the EC Treaty, has a technical meaning so that the necessary criteria for distinguishing between the act of a legislative nature and the decision within this provision need to be set up on the basis of general or other nature of the specific act."

${ }^{41}$ In the ECJ, linguistic interpretation is a less privileged method of a legal analysis. The socalled typical interpretation of Community law is primarily based on systematic and teleological interpretation - see more about this: R. Knez et al., The ECJ Decisions with Explanatory Notes, Ljubljana 2004, pp. 104-110.

${ }^{42}$ For example, in the Van Gend en Loos, Chernobyl, Extramet, and Codorniu cases.

${ }^{43}$ See Greenpeace International, C-321/95 P.

44 Partie Ecologiste 'Les Verts' v Parliament, Case 294/83, ECR 1986, p. 1339.

${ }^{45}$ Foto-Frost v Hauptzollamt Lübeck-Ost, Case 314/85, ECR 1987, p. 4199.

46 Report of the Court of Justice on certain aspects of the application of the Treaty on the European Union, Luxembourg, May 1995, http://europa.eu.int/en/agenda/igc-home/eudoc/justice/cj_rep.html.

${ }^{47}$ Case 50/2000, paragraph 45 of the judgment.

${ }^{48}$ For example, Koniklijke Scholten Honig v Council and Commission, Case 101/76, ECR 1977, p. 797, Deutsche Lebensmittlewerke v Commission, Case 97/85, ECR 1985, p. 1331, Walter Rau Lebensmittelwerke and Others $\mathrm{v}$ Bundesanstalt fur landwirtschaftliche Marktordnung, 133-136/85, ECR 1987, p. 2289.

49 Textilwerke Deggendorf v Germany, Case C-188/92, ECR 1994, p. I-833.

50 »It was only when an applicant's standing to bring annulment proceedings is clear beyond doubt that he should be prevented from challeging the validity of the act concerned before national courts.«- Opinion of Advocate General in the TWD case.

${ }^{51}$ In addition, the proceedings under Article 234 have also other shortcomings as compared to Article 230 - see the opinion of Advocate General Jacobs in the case of Unión de Pequeños Agricultores (UPA), C-50/00: in his opinion, the Advocate General has given a general assessment of the proceedings under fourth paragraph of Article 230 of the EC Treaty by saying that they are clearly more appropriate for the review of the validity of all general EC acts than the proceedings under Article 234 of the EC Treaty because the institution which has adopted the challenged act is a party to a proceeding from the beginning to the end, and because a direct action includes a full discussion unlike one-time comments followed by oral observations before the ECJ in accordance with the proceedings under Article 234 of the EC Treaty. In addition, the public is informed of the existence of the action through a notice in the Official Journal of the European Union, and third parties, if they have sufficient legal interest, may intervene under Article 37 of the Statute of the ECJ. During proceedings, the interested individuals cannot propose comments under Article 20 of the Statute, unless they intervene in a proceeding before a national court. This may be difficult because despite the fact that information on previous issues is published in the Official Journal, individuals might not be familiar with the proceedings before the national court at the initial stage when they still could intervene. It needs to be stressed that the Advocate General has stated that "for reasons of legal certainty, it is desirable to challenge the validity of EC acts as soon as possible after their adoption." Therefore, the two-month deadline laid down in Article 230 of the EC Treaty is more appropriate than the validity review under Article 234 of the EC Treaty which can "principally be launched before a national court at any time. « The stringent criteria provided by the existing case law for individuals' capacity to sue under Article 230 urge the plaintiffs to bring action before the ECJ under Article 234 of the EC Treaty, which has an effect on the reduction of legal certainty. 
52 Action for damages is provided for in the second paragraph of Article 288 of the EC Treaty which provides: "'In the case of non-contractual liability, the Community shall, in accordance with the general principles common to the laws of the Member States, make good any damage caused by its institutions or by its servants in the performance of their duties."

53 Case 4/69, ECR 1971, p. 325.

${ }^{54}$ Case 5/71, ECR 1971, p. 975.

\section{References}

Arnull A. (1995) Private Applicants and the Action for Annulment under Article 173 of the EC Treaty, Common Market Law Review, 32(7), pp. 7-49.

Arnull A. (2001), Private applicants and the action for annulment since Codorniu, Common Market Law Review, 38(1), pp. 7-52.

Costa O. (2003) The European Court of Justice and democratic control in the European Union, Journal of European Public Policy, 10(5), pp. 740-761.

Craig P. \& de Burca G. (2003) EU law, text, cases and materials, 3rd edition. (Oxford: Oxford University Press).

Gibson J.L. \& Caldeira G. A. (1998), Changes in the legitimacy of the European Court of Justice: A post-Maastricht analysis, British Journal of Political Science, 28(1), pp. 63-91.

Grilc, P. (2001) Pravo Evropske unije (Ljubljana: Pravna fakulteta Ljubljana \& Cankarjeva založba).

Hanf D. (2002) Facilitating Private Applicants' Access to the European Courts? On the Possible Impact of the CFI's Ruling in Jego-Quere, German Law Journal, 3(7), avaliable at http://www.germanlawjournal.com/past_issues.php?id=166.

Hartley, T. C. (2003) The Foundations of European Community, $5^{\text {th }}$ edition. (Oxford: Oxford University Press).

Harlow, C. (1992) 'Towards a Theory of Access for the ECJ' in Wyatt, D., Wyatt, J. \& Barav, A. (eds.) Yearbook of European Law, vol. 12 (Oxford: Oxford University Press).

Knez, R. et al. (2004) Odločitve Sodiša ES s pojasnili (Ljubljana: Nebra).

Lengauer A. (2005) Refusal of preliminary jurisdiction through the ECJ. Systematisation of declined jurisdiction and reform proposals of Art. 234 of the European Communities Treaty, Common Market Law Review, 42(2), p. 567.

Mattli W. \& Slaughter A. M. (1998) Revisiting the European Court of Justice, International Organization, 52(1), p. 177.

Rupnik, J. Cijan, R.. \& Grafenauer, B. (1996) Ustavno pravo Republike Slovenije, posebni del (Maribor: Faculty of Law Maribor).

Shaw, J. (2000) Law of the European Union, 3rd edition. (Basingstoke: Palgrawe).

Šinkovec J. (1994) Pridobljene pravice, Pravnik, 49(1/3), pp. 1-15.

Waelbroeck D. \& Fosselard D. (1995) Case Notice, Common Market Law Review, 32, pp. 257 269. 